\title{
How far do prawns and fish move into mangroves? Distribution of juvenile banana prawns Penaeus merguiensis and fish in a tropical mangrove forest in northern Australia
}

\author{
D. J. Vance*, M. D. E. Haywood, D. S. Heales, R. A. Kenyon, N. R. Loneragan, \\ R. C. Pendrey \\ CSIRO Division of Fisheries, Cleveland Marine Laboratories, PO Box 120, Cleveland, Queensland 4163, Australia
}

\begin{abstract}
It is accepted that mangroves are important nursery areas for prawns and fish, including some of major commercial importance, but little is known about how these mobile animals use the mangrove forests. We recorded the distribution of juvenile banana prawns Penaeus merguiensis and of fish in an intertidal mangrove forest adjacent to a small creek in northern Australia in November 1992 and in March 1993. Four discrete areas of the forest were enclosed with a $100 \mathrm{~m}$ long, $2 \mathrm{~mm}$ mesh stake net: 2 at the creek mangrove fringe and 2 at further distances into the mangroves. The mean distance of each sampling site inland from the creek mangrove fringe ranged from 13 to $59 \mathrm{~m}$ and the area of the sites ranged from 480 to $640 \mathrm{~m}^{2}$. Two mangrove communities, one dominated by the structurally complex Rhizophora stylosa, the other by the more open Ceriops tagal were sampled. A large size range of juvenile prawns and small fısh moved at least $43 \mathrm{~m}$ into the mangroves at high tide, and the density of prawns near the creek mangrove frunge was inversely related to the maximum tide height. The highest density of juvenile $P$. merguiensis recorded in the mangroves in November was 18.3 prawns $100 \mathrm{~m}^{-2}$ and in March was 334.5 prawns $100 \mathrm{~m}^{-2}$. Mean fish density over all samples was 83.0 fish $100 \mathrm{~m}^{-2}$ and mean fish biomass was $3.9 \mathrm{~g} \mathrm{~m}^{-2} ; 55$ species of fish were caught during the sampling. $P$. merguiensis showed no apparent preference for either of the 2 mangrove communities sampled; however, more fish (101 fish $100 \mathrm{~m}^{-2}$ ) and more fish species (26) were caught at the creek mangrove fringe site than at the other more inland sites; the lowest numbers of fish (27 fish $\left.\mathrm{m}^{-2}\right)$ and species (13) were caught at the inland site (Ceriops). On average, fish caught at the fringe site were also longer and heavier than fish caught at the other sites. By moving well into the mangrove forest, prawns and small fish are probably less vulnerable to predation by larger fish
\end{abstract}

KEY WORDS: Penaeid Mangroves · Fish - Stake net Distribution - Intertidal

\section{INTRODUCTION}

Mangrove forests are considered to be important nursery areas for prawns and fish, including many species of commercial importance. However, in many countries, they are being destroyed for woodchip production, aquaculture, housing and tourism. It is critical for the future management of these forests that we understand more clearly the relationships among

\footnotetext{
•E-mail: david.vance@gld.ml.csıro.au
}

prawns, fish and mangroves and exactly why mangroves are important to these animals.

The current view of the importance of mangroves is based mainly on studies that have shown that the juveniles of many penaeid prawns and of fish are caught near mangrove habitats (and so presumably depend. on the mangroves) and studies that have related the size of offshore catches of prawns and fish to the extent of coastal mangrove habitat (for review see Robertson $\&$ Blaber 1992). However, most of these studies, in a wide range of countries and generally involving flooded riverine forests, have been carried out in rivers 
and creeks adjacent to mangroves rather than in the intertidal mangrove forests themselves. Therefore, little is known about how mobile animals such as prawns and fish use the forests.

The banana prawn Penaeus merguiensis has been studied extensively in Australia (e.g. Rothlisberg et al. 1985, Staples et al. 1985, Haywood \& Staples 1993) because of its commercial importance. Juvenile P. merguiensis are closely associated with the mangrove habitat; they are abundant in beam trawl samples taken around low tide outside the mangroves, but are not caught once the water level rises above the mangrove line (Vance \& Staples 1992). From trap nets set in gutters draining mangrove forests, Robertson (1988) showed that juvenile $P$. merguiensis move into the mangroves on high tides, but how much of the forests they use, and what they use them for, is not clear. They may be foraging for food, seeking protection from predation or simply being passively carried by the tidal currents. Wassenberg \& Hill (1993) suggested that juvenile $P$. merguiensis may feed in the mangroves, but again, the samples were only taken with trawls outside the mangroves, when the water level was below the mangrove line. Similarly, little is known of the extent to which other prawns and fish use mangrove forests.

Some recent studies have attempted to quantify the densities of prawns and fish actually within the mangrove forests. Thayer et al. (1987), Morton (1990) and Ley et al. (1994) used stake nets to enclose areas of fringing mangroves to estimate fish densities and Sheridan (1992) used a quantitative drop sampler to estimate macrofaunal densities, including fish and prawns, amongst Rhizophora prop roots along the edge of mangrove forests. Robertson (1988) and Robertson \& Duke (1990) used a trap net to catch prawns and fish leaving mangrove forests on ebbing tides. They surveyed drainage basins within the mangroves to estimate the volume of water being fished by the net. However, no published studies have identified the extent of use of the different mangrove communities or the patterns of distribution of prawns or fish in the mangroves.

We used a stake net to obtain quantitative estimates of the abundance of prawns (in particular Penaeus merguiensis) and of fish within the mangrove forest lining a creek near Weipa in northern Australia. There are 3 main mangrove communities in the Weipa area (Long et al. 1992), characterized by their dominant species: Rhizophora stylosa, Ceriops tagal var australia and Avicennia marina var eucalyptifolia, although several other species occur in each community. We sampled in 2 of these communities (Rhizophora and Ceriops) at different distances into the mangrove forest and at varying tidal ranges.

\section{MATERIALS AND METHODS}

Mangrove sites. Sampling was carried out in a small tributary creek of the Embley River, about $17 \mathrm{~km}$ upstream from the mouth of the river (Fig. 1). This creek had been sampled regularly for 6 yr (1986 to 1992), using small beam trawls, to study the population dynamics of juvenile Penaeus merguiensis (Vance et al. 1990, Haywood \& Staples 1993). Fish were also sampled in the Embley River and similar small creeks for 3 yr (1986 to 1988) (Blaber et al. 1989).

Four stake net sites were set up in a section of the creek where 2 of the main mangrove community types (Rhizophora and Ceriops) were present in almost monospecific stands (Fig. 1). At each site, a pathway, up to $1.5 \mathrm{~m}$ wide, was cut through the mangroves to allow the net to be set from a small dinghy. Prop roots and small seedlings were cut off at ground level so that the bottom of the stake net would sit closely on the substrate. Each site was made as square as possible with sides $25 \mathrm{~m}$ long, but, to avoid damaging large trees, the pathways were sometimes irregular. Wooden stakes, extending at least $3 \mathrm{~m}$ above ground level, were driven into the substrate along the perimeter of each site about $5 \mathrm{~m}$ apart

Two sites were set up in Rhizophora at the creek fringe of the mangrove forest such that one side of each site was just outside the mangroves at the creek mangrove border (Rhizophora A and Rhizophora C) (Fig. 1). One site (Rhizophora B) was set up in Rhizophora directly inland from Rhizophora $A$ and one site was set up in the Ceriops forest about $15 \mathrm{~m}$ from Rhizophora B. The inland edges of Rhizophora B and the Ceriops site were about 48 and $75 \mathrm{~m}$, respectively, from the creek mangrove fringe and the area of each site ranged from 480 to $640 \mathrm{~m}^{2}$ (Table 1). The Ceriops site was the most elevated of the sites; the substrate height ranged from 0.91 to $1.01 \mathrm{~m}$ above the substrate height at the creek mangrove fringe. The largest height variation was at Rhizophora $\mathrm{A}$, ranging from 0 to $0.85 \mathrm{~m}$ above the fringe substrate level (Table 1).

The Rhizophora forest, with its dense prop roots, was much more structurally complex than the more open Ceriops forest. The mangrove surface area within $1 \mathrm{~m}$ of the substrate in the Rhizophora community was about 250 times the surface area of mangrove in the Ceriops community (C. A. Conacher unpubl. data).

Stake nets. Thayer et al. (1987) used a stake net to enclose sections of the narrow fringing mangrove forests common to south Florida, USA, with the shoreline forming one side of the enclosed area. We modified this technique to completely enclose areas of mangroves with a longer stake net so that we could sample the broad riverine mangrove forests more common in northern A.ustralia. The stake net used to 
Table 1. Area, minimum and maximum distances from creek mangrove fringe, and mininum and maximum substrate heights relative to the substrate level at the creek mangrove fringe for each stake net site

\begin{tabular}{|c|c|c|c|c|c|}
\hline \multirow[t]{2}{*}{ Site } & \multirow[t]{2}{*}{$\begin{array}{l}\text { Area } \\
\left(\mathrm{m}^{2}\right)\end{array}$} & \multicolumn{2}{|c|}{$\begin{array}{l}\text { Distance from creek } \\
\text { mangrove fringe (m) }\end{array}$} & \multicolumn{2}{|c|}{$\begin{array}{l}\text { Substrate height above } \\
\text { creek mangrove fringe (m) }\end{array}$} \\
\hline & & Minimum & Maximum & Minimum & Maximum \\
\hline Rhizophora A & 640 & 0 & 26 & 0.0 & 0.85 \\
\hline Rhizophora B & 480 & 25 & 48 & 0.29 & 0.87 \\
\hline Rhizophora C & 640 & 0 & 34 & 0.0 & 0.82 \\
\hline Ceriops & 580 & 43 & 75 & 0.91 & 1.01 \\
\hline
\end{tabular}

For all samples, the stake net was set as close as possible to high tide using a small dinghy. The net was first fixed to one of the wooden stakes near the lowest point of the site and then deployed as the dinghy was poled along the perimeter of the site. The net was set first along the lowest side of the site, with the codend at the lowest point. The floatline was supported by hooks on each wooden stake to keep the top of the net above the water level. The site was completely

enclose each site was $100 \mathrm{~m}$ long by $2 \mathrm{~m}$ high. The mesh was small enough $(2 \mathrm{~mm})$ to catch most Penaeus merguiensis from the time they arrive in the estuary as postlarvae (1 to $2 \mathrm{~mm}$ carapace length), as well as small fish. Galvanized chain ( $8 \mathrm{~mm}$ diameter) was inserted in a hem along the base of the nel. A codend with mouth opening of 1.0 by $0.5 \mathrm{~m} \mathrm{(2} \mathrm{and} 1 \mathrm{~mm}$ mesh) was fitted to one section of the net to concentrate trapped animals. enclosed by the net and the 2 ends were joined with velcro tape. The chain line was checked after setting to make sure it was well seated on the substrate. At all sites, the substrate was completely exposed when the water level dropped during the ebb tide. Once the water had drained from the site (after 3 to $4 \mathrm{~h}$ ), all animals trapped by the net were collected by emptying the codend, and by collecting by hand from the net or substrate close to the inner edge of the net. In all cases,

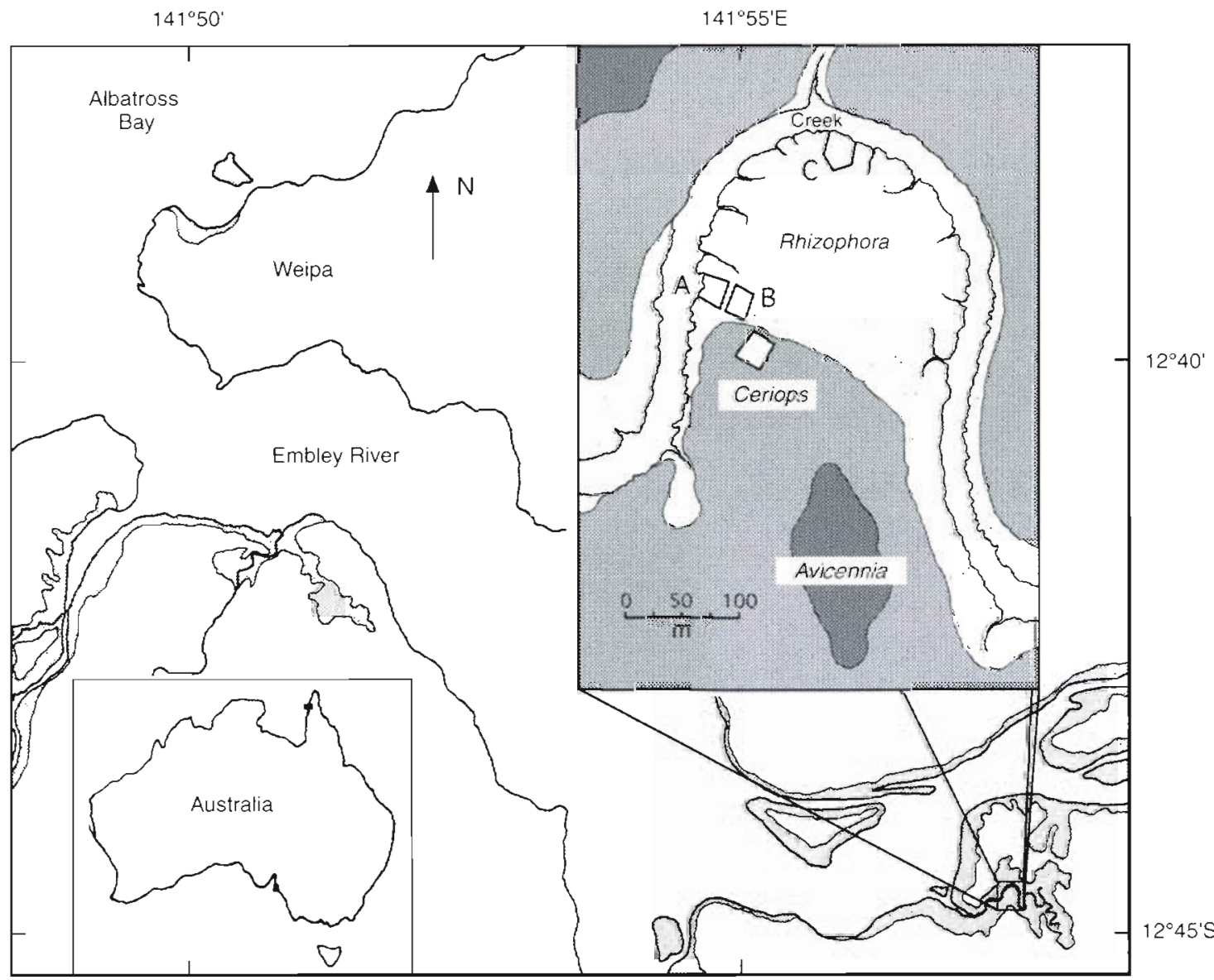

Fig. 1. Stake net sampling sites and mangrove communities in the Embley River, Gulf of Carpentaria, Australia 
Table 2. Date, location, time that the stake net was set, and the maximum tide height for each sample taken in November 1992 and March 1993

\begin{tabular}{|llcc|}
\hline Date & Location & $\begin{array}{c}\text { Time set } \\
(\mathrm{h})\end{array}$ & $\begin{array}{c}\text { Maximum tide } \\
\text { height (m) }\end{array}$ \\
\hline $22 \mathrm{Nov}$ & Rhizophora A & $16: 20$ & 2.59 \\
$23 \mathrm{Nov}$ & Rhizophora A & $17: 00$ & 2.69 \\
$24 \mathrm{Nov}$ & Ceriops & $16: 30$ & 2.76 \\
$25 \mathrm{Nov}$ & Ceriops & $16: 45$ & 2.83 \\
$26 \mathrm{Nov}$ & Rhizophora B & $17: 00$ & 2.77 \\
$27 \mathrm{Nov}$ & Rhizophora B & $17: 00$ & 2.75 \\
$22 \mathrm{Mar}$ & Rhizophora A & $18: 30$ & 2.50 \\
$23 \mathrm{Mar}$ & Rhizophora A & $18: 00$ & 2.43 \\
$25 \mathrm{Mar}$ & Rhizophora A & $07: 15$ & 2.40 \\
$26 \mathrm{Mar}$ & Rhizophora A & $08: 30$ & 2.38 \\
$28 \mathrm{Mar}$ & Rhizophora B & $08: 00$ & 2.46 \\
$29 \mathrm{Mar}$ & Rhizophora B & $09: 00$ & 2.50 \\
$30 \mathrm{Mar}$ & Rhizophora C & $09: 30$ & 2.51 \\
$31 \mathrm{Mar}$ & Rhizophora C & $09: 45$ & 2.47 \\
& & & \\
\hline
\end{tabular}

virtually no animals were seen lying on the mud in the middle or near the inner edges of the site.

Stake netting was carried out over 2 periods around spring tides at times of the year when juvenile Penaeus merguiensis are usually abundant in the estuary (Vance et al. 1990, Haywood \& Staples 1993). From. 22 to 27 November 1992, 2 samples were taken at each of 3 sites (Rhizophora A, Rhizophora B, Ceriops) (Table 2). One sample was taken each day and each site was sampled twice, on consecutive days, to investigate variation in catch rates over short time periods as well as between different tide heights. Each net was set in late afternoon, between 16:00 and 17:00 h.

From 22 to 31 March 1993, 4 samples were taken at Rhizophora $\mathrm{A}$ and 2 samples each were taken at Rhizophora B and Rhizophora C (Table 2). The net was set just before dusk for the first 2 samples on consecutive days at Rhizophora A. No samples were taken on 24 March, but then 2 more samples were taken on consecutive days at Rhizophora $A$ with the net set in the morning between 07:15 and 08:30 h (Table 2). The time of sampling changed because the relative height of the 2 tides in each 24 h period changed; only 11 of the 20 high tides between 22 and 31 March inundated the mangroves. The net was not set on 27 March and the remaining samples at Rhizophora B and Rhizophora $\mathrm{C}$ were taken with the net set between 08:00 and 09:45 h each day. Tide heights were not high enough in March to allow the stake net to be set at the Ceriops site.

Beam trawls. For each spring low tide during the stake netting in November 1992 and March 1993, a series of samples was taken with a small beam trawl to compare stake net catches of Penaeus merguiensis with this more commonly used method. A 1.0 by $0.5 \mathrm{~m}$ beam trawl with a $2 \mathrm{~mm}$ mesh net and $1 \mathrm{~mm}$ codend was towed from a small dinghy just before low tide when the water level was below the mangrove forest and $P$. merguiensis catchability was highest (Vance \& Staples 1992). Trawls were made at 2 locations: close to the exposed mudbank in front of Rhizophora $\mathrm{A}$ and about $1 \mathrm{~km}$ further upstream at a site that had been regularly trawled over 6 yr (Vance et al. 1990). At each location, one $50 \mathrm{~m}$ trawl was made parallel to the bank in about $0.5 \mathrm{~m}$ depth of water, and 4 random perpendicular trawls, each of $10 \mathrm{~m}$ length, were made from the water's edge towards the middle of the creek. The density (no. $\mathrm{m}^{-2}$ ) for each sampling session at the trawl sites was calculated as the mean catch for the 5 trawls.

Prawns were identified to genus and those of the genus Penaeus to species. They were measured to the nearest $1.0 \mathrm{~mm}$ carapace length (CL) using a binocular microscope fitted with an ocular micrometer. Fish were identified to species and the standard length (SL) was measured to the nearest $1.0 \mathrm{~mm}$. The weight of each fish was recorded to the nearest $0.1 \mathrm{~g}$.

Fish that prey on penaeid prawns in the Embley River have been identified by Salini et al. (1990), who sampled in this estuary with gill and seine nets and rotenone on 6 occasions between 1986 and 1988. We used their data on predator species of prawns to calculate the total number of predators caught in each of our samples.

Water temperature and salinity were recorded near high tide when each stake net was set and near low tide when the trawl samples were taken. Hourly tide heights recorded by an automatic tide gauge near the mouth of the Embley River were provided by the Beach Protection Authority, Queensland, and the Queensland Department of Transport, Marine and Ports Division, Australia.

To test whether the distribution of prawns and fish was influenced by changes in the tidal inundation of the mangroves, densities from March samples were compared with the maximum recorded tide height for each sample using correlation analysis (SAS Institute 1990). November samples were not used in this analysis due to the lower number of data points

\section{RESULTS}

\section{Environment}

Tides in the Embley River are semidiurnal but the 2 tides in each $24 \mathrm{~h}$ period are of unequal range. The maximum recorded tide height for each sample during November ranged from 2.59 to $2.83 \mathrm{~m}$, which meant that water inundated all the mangrove forest at the time that each stake net was set (Table 2). During the 

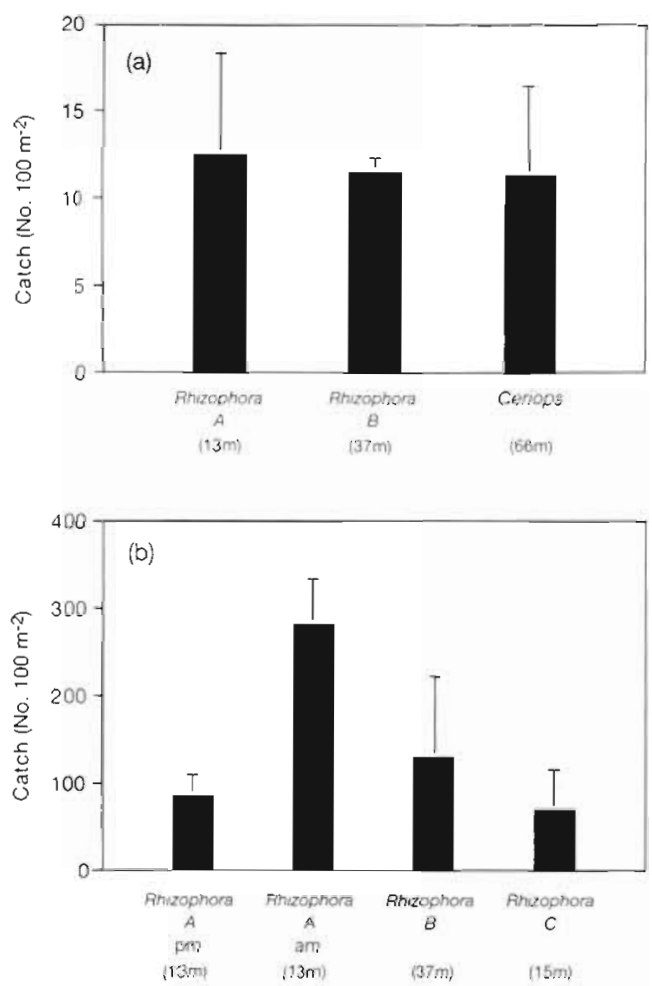

Fig. 2. Penaeus merguiensis. Mean stake net catches (+1 SE) for 2 samples each at (a) Rhizophora A, Rhizophora B and Ceriops sites from 22 to 27 November 1992, and (b) Rhizophora $\mathrm{A}$ in the late afternoon (pm), Rhizophora $\mathrm{A}$ in the morning (am), Rhizophora B and Rhizophora C sites from 22 to 31 March 1993. Mean distances of each site inland from the creek mangrove fringe are given in parentheses

March sampling, however, the high tides were lower, ranging from 2.38 to $2.51 \mathrm{~m}$. On the lowest high tide in March, the water level did not reach the inland edge of the Rhizophora forest, whereas on the highest tide, the water level nearly reached the inland edge of the Ceriops forest. Water depth at the creek mangrove fringe at high tide ranged from 0.8 to $1.5 \mathrm{~m}$ over all samplings.

Water temperatures varied little, ranging from 29.4 to $31.3^{\circ} \mathrm{C}$ throughout the November and March sampling periods. Salinity variation was greater: in November, salinities ranged from 36.9 to $41.7 \%$ but were much lower in March, ranging from 9.5 to $16.6 \%$.

\section{Penaeus merguiensis}

Catches of Penaeus merguiensis in November 1992 varied substantially between individual stake net samples at Rhizophora $\mathrm{A}$ and also between samples at the Ceriops site. The highest catch was 18.3 prawns $100 \mathrm{~m}^{-2}$ at Rhizophora A and the lowest catch was 6.2 prawns $100 \mathrm{~m}^{-2}$ at the Ceriops site. However, the mean
Catch over 2 samples was similar for all sites (Fig. 2a) Catches were much higher and even more variable in March 1993, ranging from 334.5 prawns $100 \mathrm{~m}^{-2}$ at Rhizophora A in the morning to 23.4 prawns $100 \mathrm{~m}^{-2}$ at Rhizophora $\mathrm{C}$. The mean catch for the morning samples at Rhizophora A was much higher than the mean catch for any of the other pairs of samples (Fig. 2b).

Densities of Penaeus merguiensis in March in the Rhizophora forest were negatively correlated with the maximum tide height recorded for each sample $\left(\mathrm{R}^{2}=\right.$ 0.79, $\mathrm{p}=0.003, \mathrm{n}=8$ ) (Fig. 3). The correlation was significant for all sizes of prawns caught. Correlations were not calculated for the November samples as there were too few data points.

A wide size range of Penaeus merguiensis was caught in the stake nets in November and March. The pattern of length-frequency distributions was different for each sampling period (Fig. 4a, b). In November, very few 1 and $2 \mathrm{~mm} \mathrm{CL}$ prawns were caught, whereas in March, when mangrove inundation was less, these were the most abundant sizes. However, 1 and $2 \mathrm{~mm}$ CL prawns dominated catches taken in beam trawls outside the mangroves near low tide in both months (Fig. 4c, d). A larger proportion of prawns $>3 \mathrm{~mm} C \mathrm{CL}$ were caught in the stake nets than in beam trawls in both November and March.

The largest prawns caught in the stake nets were 14 and $20 \mathrm{~mm}$ CL in November and March, respectively, while the largest prawns caught in trawls in the same months were 11 and $14 \mathrm{~mm}$ CL. Mean Penaeus merguiensis catch over all trawls at the long-term trawl site was 4.2 prawns $\mathrm{m}^{-2}$ in November and 20.4 prawns $\mathrm{m}^{-2}$ in March.

When pairs of samples taken from each site on consecutive days were compared, there was no consistent

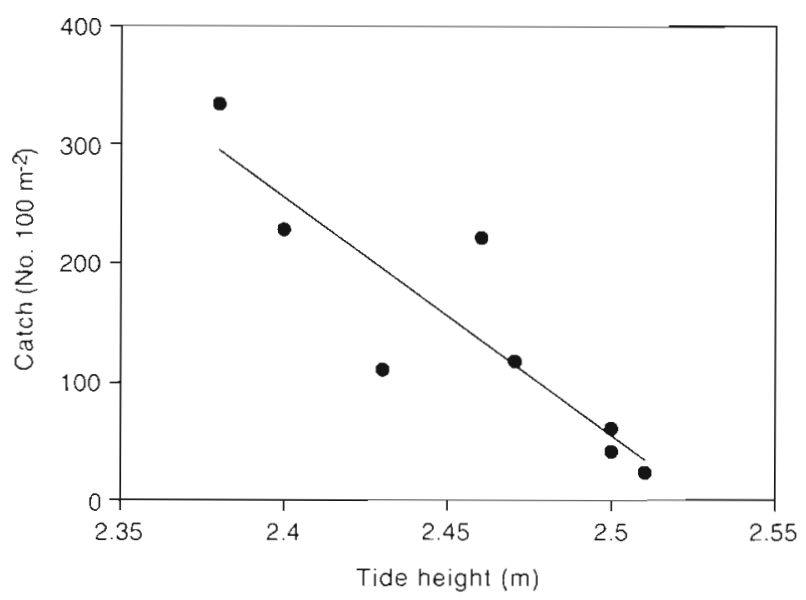

Fig. 3. Penaeus mergusensis. Relationship between stake net catches and the maximum observed tide height for each sample taken in the Rhizophora forest from 22 to 31 March 1993 


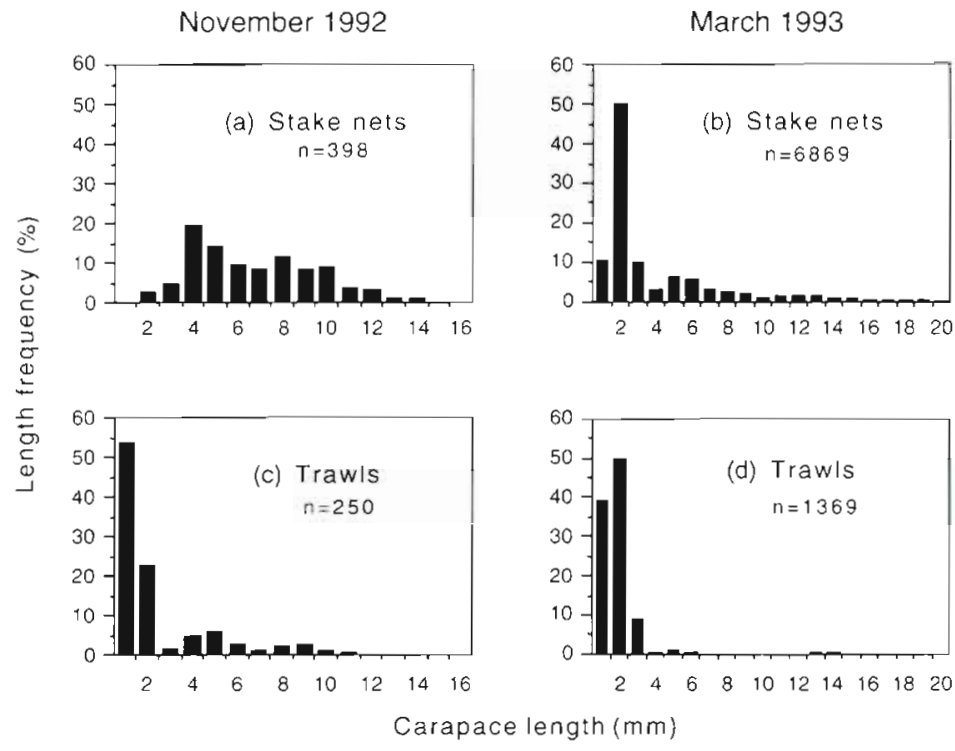

Fig. 4. Penaeus merguiensis. Length-frequency distributions for stake nets and beam trawls for all samples from $(a, c) 22$ to 27 November 1992 and $(b, d) 22$ to 31 March 1993. n = total number of prawns caught

difference in catch rates between the first and second samples for prawns of any size.

\section{Fish}

A total of 2280 fish of 44 species were caught in the 6 stake net samples in November and 4602 fish of 47 species were caught in 8 samples in March; 55 species were caught overall (Table 3 ) and 32 species were caught in both November and March. Over $90 \%$ of the total number and over $80 \%$ of the biomass of fish caught in each month were from species that were caught in both months. A large size range of fish was caught: from $<10 \mathrm{~mm}$ SL (scatophagids and leiognathids) to $590 \mathrm{~mm}$ SL (catfish eel) (Table 3). Only 59 of the fish ( 9 species) caught in November, and 61 of the fish (8 species) caught in March were known to eat prawns in the Embley River.

There were clear differences in the distribution of fish among the 3 stake net sites in November (Fig. 5). More fish (101 fish $100 \mathrm{~m}^{-2}$ ) and more species (26) were caught at the creek mangrove fringe (Rhizophora A) than in either of the other sites; the lowest number of fish (27 fish $\mathrm{m}^{-2}$ ) and species (13) were caught at the inland site (Ceriops) (Fig. 5a, b). Fish caught at the creek fringe site also had the largest mean length and mean weight of the 3 sites (Fig. 5c, d); virtually all the larger predatory fish (e.g. Arius thalassinus, A. graeffei. Caranx sexfasciatus, Lates calcarifer and Platycephalus indicus) were caught only at this site. Only 9 of the 44 species were caught in greater numbers at the Ceriops site than at the creek mangrove fringe (Rhizophora A); the most abundant of these was Ambassis gymnocephalus (n = 151, maximum size $28 \mathrm{~mm} \mathrm{SL}$ ). The largest mean biomass $( \pm 1 \mathrm{SE})$ of fish was taken at the creek mangrove fringe, Rhizophora $A$ $\left(8.9 \pm 0.14 \mathrm{~g} \mathrm{~m}^{-2}\right)$, while the lowest mean biomass was taken at the Ceriops site $(1.03 \pm$ $0.10 \mathrm{~g} \mathrm{~m}^{-2}$.

In March, the Ceriops site was not sampled, and the comparison between creek mangrove fringe and inland site was not as marked. However, mean fish length, mean fish weight and the mean number of fish species were all lowest at the inland Rhizophora site (Rhizophora B). The mean density of fish at Rhizophora B was between the densities at the 2 creek fringe sites (Rhizophora A and C).

Catch rates (no. $100 \mathrm{~m}^{-2}$ ) of all tish species combined were negatively correlated with the maximum tide height for each sample in March at the Rhizophora sites $\left(\mathrm{R}^{2}=0.57, \mathrm{p}=\right.$ $0.03, \mathrm{n}=8)$. However, the biomass $\left(\mathrm{g} \mathrm{m}^{-2}\right)$ of fish for each sample was not related to tide height $\left(R^{2}=0.02\right.$, $p=0.73, n=8$ ). We found a similar result when only fish that are known predators of penaeid prawns in this estuary (Salini et al. 1990) were used in the analysis, but the correlation for catch rates and tide heights was lower than for all species $\left(R^{2}=0.48, p=0.08, n=7\right)$.

When pairs of samples taken from each site on consecutive days were compared, there was no consistent difference in catch rates for fish $<100 \mathrm{~mm}$ SL between the first and second samples (Table 4). However, for fish $\geq 100 \mathrm{~mm}$ SL, there were always fewer fish caught in the second sample than in the first sample.

\section{DISCUSSION}

\section{Penaeus merguiensis distribution}

Clearly, juvenile Penaeus merguiensis move substantial distances into the mangrove forests on high tides. In November 1992, prawns were caught at least $43 \mathrm{~m}$ into the mangroves. The sampling in March 1993 at the creek mangrove fringe suggested that the distance they moved into the mangroves depended on tide height. Densities of $P$. merguiensis declined as the maximum tide height increased, suggesting that prawns moved further into the mangrove forest from the creek fringe as the tide height increased. However, they were not just following the water's edge into the mangroves, as prawns were still caught at the creek mangrove fringe when the water had inundated the in- 
Table 3. Total number, length range, mean length, weight range and mean weight of all fish caught in all stake net samples from 22 to 27 November 1992 and from 22 to 31 March 1993. 'Species which had not previously been caught in similar small creeks in the Embley River

\begin{tabular}{|c|c|c|c|c|c|c|}
\hline Family & Species & $\begin{array}{c}\text { Total } \\
\text { no. }\end{array}$ & $\begin{array}{c}\text { Length } \\
\text { range } \\
\text { (mm) }\end{array}$ & $\begin{array}{c}\text { Mean } \\
\text { length } \\
(\mathrm{mm})\end{array}$ & $\begin{array}{c}\text { Weight } \\
\text { range } \\
\text { (g) }\end{array}$ & $\begin{array}{c}\text { Mean } \\
\text { wt } \\
(g)\end{array}$ \\
\hline \multirow[t]{3}{*}{ Ambassidae } & Ambassis gymnocephalus & 578 & $11-41$ & 24 & $0.1-1.9$ & 0.4 \\
\hline & Ambassis nalua & 9 & $20-68$ & 45 & $0.3-12.4$ & 4.5 \\
\hline & Ambassis vachellii & 23 & $23-44$ & 39 & $0.3-2.4$ & 1.7 \\
\hline \multirow[t]{2}{*}{ Ariidae } & Arius graeffei & 2 & $270-356$ & 313 & $361.0-706.1$ & 533.6 \\
\hline & Arius thalassinus & 1 & $370-370$ & 370 & $750.0-750.0$ & 750.0 \\
\hline Belonidae & Strongylura strongylura & 7 & $109-285$ & 156 & $1.5-35.0$ & 7.7 \\
\hline Blenniidae & Omobranchus rotundiceps & 3 & $36-44$ & 39 & $0.6-1.1$ & 0.8 \\
\hline Carangidae & Caranx sexfasciatus & 2 & $95-99$ & 97 & $25.8-30.5$ & 28.2 \\
\hline Centropomidae & Lates calcarifer & 11 & $172-377$ & 286 & $113.0-820.0$ & 521.4 \\
\hline \multirow[t]{5}{*}{ Clupeidae } & Anodontostoma chacunda & 25 & $42-77$ & 60 & $1.7-13.3$ & 6.7 \\
\hline & Esculosa thoracata & 26 & $21-39$ & 25 & $0.1-0.9$ & 0.2 \\
\hline & Herklotsichthys lippa & 150 & $21-32$ & 27 & $0.2-0.5$ & 0.3 \\
\hline & Nematalosa come. & 805 & $18-145$ & 29 & $0.1-70.1$ & 0.6 \\
\hline & Sardinella albella & 1417 & $22-64$ & 38 & $0.2-6.0$ & 1.2 \\
\hline Dasyatididae & Himantura granulata. & 5 & $38-335$ & 152 & $0.5-1990.0$ & 649.3 \\
\hline \multirow[t]{4}{*}{ Eleotridae } & Bostrichthys sinensis & 2 & $40-127$ & 84 & $1.5-34.3$ & 17.9 \\
\hline & Butis butis. & 323 & $10-84$ & 24 & $0.1-11.2$ & 0.4 \\
\hline & Ophiocara porocephala. & 3 & $142-198$ & 161 & $85.7-203.3$ & 125.4 \\
\hline & Prionobutis microps & 9 & $22-33$ & 28 & $0.3-0.6$ & 0.5 \\
\hline \multirow[t]{2}{*}{ Engraulididae } & Stolephorus carpentariae & 121 & $21-40$ & 25 & $0.1-0.6$ & 0.2 \\
\hline & Thryssa hamiltoni & 51 & $26-53$ & 36 & $0.1-1.6$ & 0.6 \\
\hline Ephippididae & Zabidius novemaculatus ' & 6 & $15-25$ & 18 & $0.3-1.0$ & 0.5 \\
\hline Gerreidae & Gerres filamentosus & 14 & $12-83$ & 17 & $0.1-19.0$ & 1.5 \\
\hline \multirow[t]{5}{*}{ Gobiidae } & Acentrogobius viridipunctatus & 7 & $28-80$ & 65 & $0.5-12.8$ & 7.2 \\
\hline & Drombus globiceps & 450 & $11-32$ & 20 & $0.1-0.6$ & 0.2 \\
\hline & Drombus ocyurus & 1 & $27-27$ & 27 & $0.6-0.6$ & 0.6 \\
\hline & Drombus spp. & 12 & $16-31$ & 19 & $0.2-0.7$ & 0.3 \\
\hline & Pseudogobius avicennla & 22 & $13-15$ & 14 & $0.1-0.1$ & 0.1 \\
\hline Haemulidae & Pomadasys kaakan & 6 & $34-159$ & 58 & $1.1-115.3$ & 20.5 \\
\hline \multirow[t]{2}{*}{ Hemiramphidae } & Arrhamphus sclerolepis & 8 & $73-159$ & 109 & $3.0-38.0$ & 14.3 \\
\hline & Zenarchopterus buffonis & 264 & $19-129$ & 61 & $0.1-21.6$ & 3.6 \\
\hline \multirow[t]{2}{*}{ Leiognathidae } & Leiognathus decorus & 105 & $9-30$ & 17 & $0.1-0.7$ & 0.2 \\
\hline & Leiognathus equulus & 4 & $18-22$ & 19 & $0.1-0.3$ & 0.2 \\
\hline \multirow[t]{3}{*}{ Lutjanidae } & Lutjanus argentimaculatus & 10 & $114-237$ & 194 & $50.5-337.6$ & 239.3 \\
\hline & Lutjanus johnii & 1 & $168-168$ & 168 & $158.4-158.4$ & 158.4 \\
\hline & Lutjanus russelli & 1 & $69-69$ & 69 & $9.8-9.8$ & 9.8 \\
\hline \multirow[t]{2}{*}{ Melanotaeniidae } & Melanotaenia splendida & 1 & $44-44$ & 44 & $1.9-1.9$ & 1.9 \\
\hline & Pseudomugil gertrudae & 2191 & $10-24$ & 16 & $0.1-0.2$ & 0.1 \\
\hline Monodactylidae & Monodactylus argenteus & 6 & $21-59$ & 41 & $0.6-13.2$ & 6.0 \\
\hline \multirow[t]{2}{*}{ Mugilidae } & Liza subviridis & 30 & $35-260$ & 94 & $1.1-319.9$ & 31.2 \\
\hline & Valamugil buchanani & 4 & $122-163$ & 149 & $43.3-109.0$ & 80.0 \\
\hline Platycephalidae & Platycephalus indicus ${ }^{\circ}$ & 3 & $270-373$ & 316 & $150.0-450.0$ & 304.8 \\
\hline \multirow{2}{*}{ Plotosidae } & Euristhmus lepturus ${ }^{\circ}$ & 1 & $590-590$ & 590 & $1411.1-1411.1$ & 1411.1 \\
\hline & Euristhmus nudiceps & 10 & $32-242$ & 55 & $0.2-77.6$ & 8.0 \\
\hline \multirow[t]{2}{*}{ Scatophagidae } & Scatophagus argus & 23 & $7-190$ & 16 & $0.1-375.0$ & 16.4 \\
\hline & Selenotoca multifasciata. & 2 & $130-172$ & 151 & $90.9 \cdot 186.9$ & 138.9 \\
\hline Serranidae & Epinephelus suillus ${ }^{\circ}$ & 2 & $240-304$ & 272 & 450.6 .718 .4 & 584.5 \\
\hline Soleidae & Achirus rautheri & 1 & $62-62$ & 62 & $4.3-4.3$ & 4.3 \\
\hline Sparidae & Acanthopagrus berda & 54 & $30-246$ & 124 & $1.2-603.8$ & 132.2 \\
\hline Sphyraenidae & Sphyraena qenie. & 3 & $237-455$ & 353 & $115.1-722.6$ & 405.2 \\
\hline \multirow{3}{*}{$\begin{array}{l}\text { Spnyraeniade } \\
\text { Tetraodontidae }\end{array}$} & Chelonodon patoca & 2 & $28-34$ & 31 & $1.5-2.4$ & 2.0 \\
\hline & Marilyna darwinii & 4 & $13-26$ & 19 & $0.3-0.6$ & 0.5 \\
\hline & Tetraodon erythrotaenia & 27 & $26-60$ & 40 & $1.5-13.1$ & 5.0 \\
\hline Teraponidae & Terapon puta. & 2 & $12-14$ & 13 & $0.1-0.1$ & 0.1 \\
\hline Toxotidae & Toxotes chatareus & 33 & $25-159$ & 79 & $0.2-168.5$ & 36.5 \\
\hline
\end{tabular}



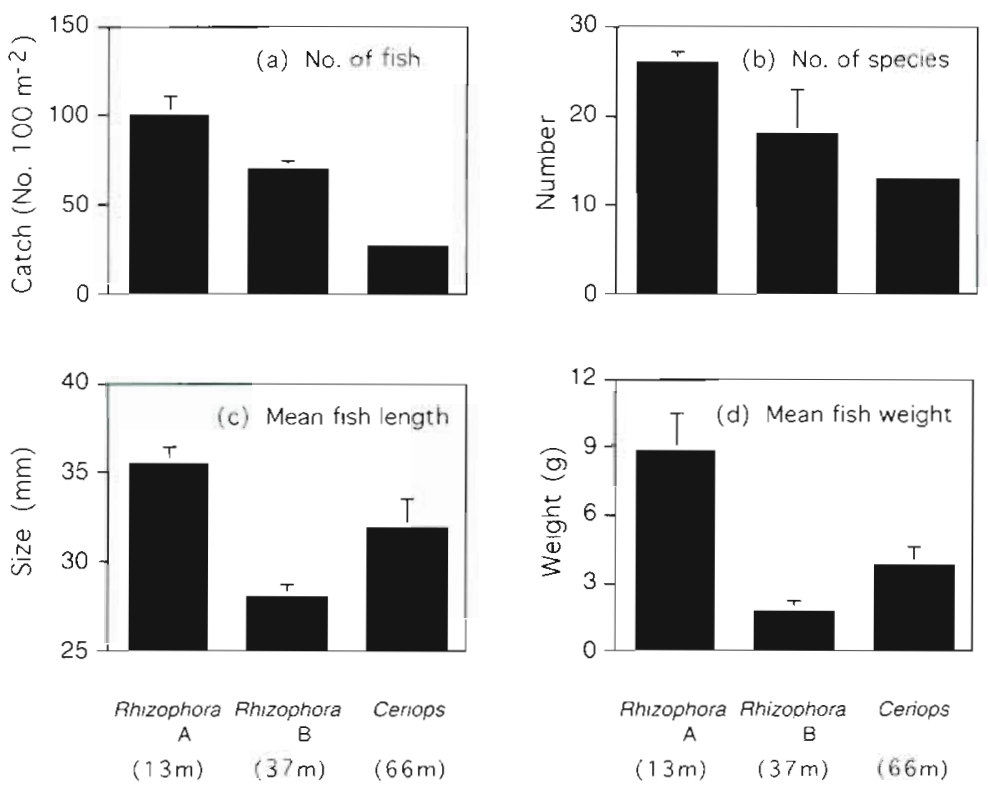

Fig. 5. Mean (+1 SE) of data for all fish caught in 2 samples each at Rhizophora A, Rhizophora B and Ceriops sites from 22 to 27 November 1992. Mean distances of each site inland from the creek mangrove fringe are given in parentheses

land mangrove fringe. Juvenile P. merguiensis appear, therefore, to use a large part of the mangrove forest.

Juvenile Penaeus merguiensis did not appear to prefer either the Rhizophora or Ceriops communities sampled in November. The mean densities in the Rhizophora were very similar to those in the Ceriops forest, despite the vast difference in morphology of the 2 communities. The very dense prop root structure of the Rhizophora forest was substantially more complex than that of the open Ceriops forest.

A large size range of Penaeus merguiensis moved well into the mangrove forest (at least $43 \mathrm{~m}$ ). The stake net was more effective at catching the larger prawns in the mangrove forest than was the beam trawl outside the mangroves. The larger prawns are probably better at avoiding the small beam trawl than are the small prawns, and they also may not concentrate at the shallow water's edge as much as the small prawns do (Staples \& Vance 1979). The reason for the lower catches of 1 and $2 \mathrm{~mm} \mathrm{CL}$ prawns in the November stake nets as compared to the trawls and the March stake nets is not clear. Possibly, these very small prawns are less able to control their movements in the water column and are therefore swept further into the mangroves by the tides. On. the higher tides in November, most of the 1 and $2 \mathrm{~mm} \mathrm{CL}$ prawns may therefore have been moved further into the mangroves, beyond our sampling sites.

\section{Fish distribution}

Stake netting appears to be a very effective technique for sampling small fish in mangrove-lined creeks. Eighteen species of fish caught in these samples had not been previously caught when similar small creeks and inlets of the Embley River were sampled with gill nets or rotenone (Blaber et al. 1989), although some of them had been caught in other habitats of the river.

The patterns of fish distribution were more complicated than Penaeus merguiensis distribution patterns, as would be expected given the variety of species caught. From the November sampling, it is clear that not all fish species moved as far into the mangroves as the juvenile $P$. merguiensis. Large fish tended to remain near the creek mangrove fringe, while small fish were found at all sites. The most abundant fish caught at the Ceriops site (furthest in from the creek fringe) were relatively small; however, of 21 fish larger than $200 \mathrm{~mm}$ SL caught in November, 20 were caught at the creek fringe site (Rhizophora A). Only $120(1.7 \%)$ of the 6884 fish caught in all stake nets were from species that are known to eat juvenile penaeid prawns in the Embley River; however, they constituted $55 \%$ of the total fish biomass.

A consequence of the differences in distribution between the juvenile Penaeus merguiensis and large fish is that the juvenile prawns and small fish that move a substantial distance into the mangroves probably gain some protection from predation by the larger fish

In Robertson \& Blaber's (1992) review of fish density and biomass values for tropical and subtropical man-

Table 4. Total number of 3 size classes of fish caught in stake nets set on 2 consecutive days in November 1992 and March 1993. Set 1 first sample, Set 2: second sample

\begin{tabular}{|c|c|c|c|c|c|c|}
\hline Date and location & \multicolumn{2}{|c|}{$<50 \mathrm{~mm}$} & $\begin{array}{l}50 \text { 10 } \\
\text { Set } 1\end{array}$ & $\begin{array}{c}99 \mathrm{~mm} \\
\text { Set } 2\end{array}$ & $\begin{array}{l}\geq 100 \\
\text { Set } 1\end{array}$ & $\begin{array}{l}\mathrm{mm} \\
\text { Set } 2\end{array}$ \\
\hline November 1992 & & & & & & \\
\hline Rhizophora A & 490 & 684 & 73 & 10 & 21 & 18 \\
\hline Rhizophora B & 296 & 354 & 12 & 8 & 10 & 6 \\
\hline Ceriops & 137 & 139 & 11 & 1 & 8 & 4 \\
\hline March 1993 & & & & & & \\
\hline Rhizophora A pm & 512 & 678 & 27 & 32 & 22 & 1.8 \\
\hline Rhizophora A am & 678 & 900 & 33 & 27 & 18 & 7 \\
\hline Rhizophora B & 701 & 153 & 26 & 5 & 13 & 7 \\
\hline Rhizophora C & 220 & 482 & 13 & 20 & 7 & 3 \\
\hline
\end{tabular}


grove systems, they pointed out the difficulties of comparing studies that used different gears and sampled different microhabitats. Very few published studies have recorded fish abundances in mangrove forests and they have all sampled mangroves at the creek mangrove fringe. None have attempted to sample discrete areas inside the mangrove forest. Thayer et al. (1987) in Florida, USA, and Morton (1990) in Australia used stake nets; Sheridan (1992), also in Florida, used a drop sampler to sample fish in mangrove forests. The mean fish density recorded by Morton (1990) (0.27 fish $\left.\mathrm{m}^{-2}\right)$ was lower and those by Thayer et al. (1987) (8.0 fish $\mathrm{m}^{-2}$ ) and Sheridan (1992) (5.9 fish $\mathrm{m}^{-2}$ ) were higher than the mean density for all our samples $\left(0.83\right.$ fish $\left.\mathrm{m}^{-2}\right)$. The mean fish biomasses recorded by Morton (1990) (25.3 $\mathrm{g} \mathrm{m}^{-2}$ ) and Thayer et al. (1987) (15.0 $\mathrm{g} \mathrm{m}^{-2}$ ) were both much higher than the mean biomass of fish caught in all our samples $\left(3.9 \mathrm{~g} \mathrm{~m}^{-2}\right)$ or by Sheridan (1992) (4 $\left.\mathrm{g} \mathrm{m}^{-2}\right)$.

The reasons for the differences in numbers and biomass between our study and those of Thayer et al. (1987) and Morton (1990) may be different for each study. The fish biomass in Morton's study was dominated by 1 species of Kyphosidae (Girella tricuspidata), which made up $67 \%$ of the biomass and which has not been reported in the Embley River. The mangrove forests Thayer sampled were only 5 to $10 \mathrm{~m}$ wide. which is typical of the fringing mangrove habitats of south Florida, whereas our outer mangrove sites were about $25 \mathrm{~m}$ wide. Possibly, most of the larger fish are restricted to the first 5 to $10 \mathrm{~m}$ of mangroves, and by sampling deeper into the mangroves where densities of larger fish were lower, we were masking the higher biomass at the mangrove fringe.

\section{Consecutive samples}

There was no consistent difference in catches of either juvenile Penaeus merguiensis or small fish between consecutive samples taken at each site. However, catches of the larger fish (>100 mm SL) were always lower in the second sample. Morton (1990) noted a similar effect in his stake net sampling in Moreton Bay. He speculated that physical disturbance of the substrate during fish collection may have released repelling substances, or that it was simply an effect of removing these fish from the resident population. In our sampling, it is more likely to have been the latter, as repelling substances would presumably have affected all sizes of fish, not just the large ones. In our future work, sites will not be sampled on consecutive days.

Although the samples in November and March were taken over 6 and $10 \mathrm{~d}$ respectively, it is unlikely that any of the variation in catches of Penaeus merguiensis or fish was due to animals moving out of the estuary. Changes in salinity are often associated with emigration of juvenile $P$. merguiensis from estuaries (Staples \& Vance 1986) but salinity did not change substantially in the creek over this time. It is also unlikely that construction of the pathways around each site would have substantially changed the distribution of animals in the mangroves, as similar open areas occur naturally in other parts of the forest, and the pathways were not wide in relation to the width of mangrove forest being sampled.

\section{Sampling techniques}

Stake netting is a very useful quantitative technique for sampling prawns and fish that move into and out of intertidal areas. With the small mesh $(2 \mathrm{~mm})$ of our stake net, it was clearly possible to catch a large size range of prawns and fish. Other techniques, however, such as beam trawls and gill nets, are much more selective for size and species of animal caught (e.g Young \& Wadley 1979). Large prawns and fast-moving fish can easily evade small beam trawls, while gill nets are most effective at catching highly mobile fish and least effective at catching slow-moving and sedentary fish. Our stake net enclosed a known area of substrate, and therefore could be used to make estimates of prawn and fish densities, although, as with other techniques, the net efficiency would be less than $100 \%$, and probably different for each species of fish and prawn (Thayer et al. 1987. Morton 1990). Beam trawls can provide estimates of densities per area of substrate trawled, but this is extremely difficult to do with gill nets, which are passive samplers. Seine nets can sample a wide size range of animals and a known area, but are mostly limited to operations near the water's edge.

Neither beam trawls, gill nets nor seine nets are practical methods with which to sample fish and prawns within dense mangrove forests. Although time must be spent preparing the site, stake netting can provide good data on the distributions of a wide range of prawns and fish within mangrove forests.

\section{Conclusions}

It is clear that a wide size range of juvenile Penaeus merguiensis moved substantial distances into the mangrove forests at high tide. Many small fish also moved well into the forests, but the larger fish were found only in the outer fringing mangroves. The type of mangrove did not seem to affect the distribution of prawns. Stake netting, although time-consuming, seems to be 
an excellent method for studying the distribution and movements of mobile animals within intertidal mangrove forests.

Acknowledgements. We thank Mr Geoff Carey, Ms Carol Conacher and Ms Megan Kempster for enthusiastic and patient help in the field and Mr Michael O Neill who identified and measured most of the fish. Dr Steve Blaber and $\mathrm{Mr}$ John Salini of the CSIRO Division of Fisheries, Clevelund, Dr Chris O'Brien of the Bureau of Resource Sciences, Canberra, and Dr Vivienne Mawson of the CSIRO Division of Fisheries Hobart, made useful suggestions for changes to the manuscript. This study was funded by the Fisheries Research and Development Corporation (FRDC 92/45) and by the CSIRO Division of Fisheries

\section{LITERATURE CITED}

Blaber SJM, Brewer DT, Salini JP (1989) Species composition and biomasses of fishes in different habitats of a tropical northern Australian estuary: their occurrence in the adjoining sea and estuarine independence. Estuar coast Shelf Sci 29:509-531

Haywood MDE, Staples DJ (1993) Field estimates of growth and mortality of juvenile banana prawns (Penaeus merguiensis). Mar Biol 1.16:407-416

Ley JA, Montague CL, McIvor CC (1994) Food habits of mangrove fishes: a comparison along estuarine gradients in northeastern Florida Bay. Bull mar Sci 54:881-899

Long BG, Vance DJ, Conacher CA (1992) Remote sensing helps identify links between mangroves and prawns. Aust Fish 51:22-23

Morton RM (1990) Community structure, density and standing crop of fishes in a subtropical Australian mangrove area. Mar Biol 105:385-394

Robertson Al (1988) Abundance, diet and predators of juvenile banana prawns, Penaeus merguiensis, in a tropical mangrove estuary. Aust J mar Freshwat Res 39:467-478

Robertson AI, Blaber SJM (1992) Plankton, epibenthos and fish communities. In: Robertson AI, Alongi DM (eds) Tropical mangrove ecosystems (Coastal and estuarine studies; 41). American Geophysical Union, Washington DC, p $173-224$

Robertson AI, Duke NC (1990) Mangrove ftsh-communities tn tropical Queensland, Australia: spatial and temporal

This article was submitted to the editor patterns in densities, biomass and conmunity structure. Mar Biol 104:369-379

Rothlisberg PC, Staples DJ, Crocos PJ (1985) A review of the life history of the banana prawn, Penaeus merguiensis in the Gulf of Carpentaria. In: Rothlisberg PC. Hill BJ, Staples DJ (eds) Second Aust Nat Prawn Sem, NPS2, Cleveland, Australia, p 125-136

Salinı JP, Blaber SJM, Brewer DT (1990) Diets of piscivorous fishes in a tropical Australian estuary, with special reference to predation on penaeid prawns. Mar Biol 105: $363-374$

SAS Institute, Inc (1990) SAS procedures guide, version 6, 3rd edn. SAS Institute Inc, Cary, NC

Sheridan PF (1992) Comparative habitat utilization by estuarine macrofauna within the mangrove ecosystem of Rookery Bay, Florida. Bull mar Sci 50:21-39

Staples DJ, Vance DJ (1979) Effects of changes in catchability on sampling of juvenile and adolescent prawns, Penceus merguensis de Man. Aust J mar Freshwat Res 30:511-519

Staples DJ, Vance DJ (1986) Emigration of juvenile banana prawns Penaeus merguiensis from a mangrove estuary and recruitment to offshore areas in the wet-dry tropics of the Gulf of Carpentaria, Australia. Mar Ecol Prog Ser 27 . $239-252$

Staples DJ, Vance DJ, Heales DS (1985) Habitat requirements of juvenile penaeid prawns and their relationship to offshore fisheries. In: Rothlisberg PC, Hill BJ, Staples DJ (eds) Second Aust Nat Prawn Sem, NPS2, Cleveland, Australia, p $47-54$

Thayer GW, Colby DR, Hettler Jr WF (1987) Utilization of the red mangrove prop root habitat by fishes in south Florida. Mar Ecol Prog Ser 35:25-38

Vance DJ, Haywood MDE, Staples DJ (1990) Use of a mangrove estuary as a nursery area by postlarval and juvenile banana prawns, Penaeus merguiensis de Man, in northern Australia. Estuar coast Shelf Sci 31:689-701

Vance DJ, Staples DJ (1992) Catchability and sampling of three species of juvenile penaeid prawns in the Embley River, Gulf of Carpentaria, Australia. Mar Ecol Prog Ser $87: 201-21.3$

Wassenberg TJ, Hill BJ (1993) Diet and feeding behaviour of juvenile and adult banana prawns Pendeus merguiensis in the Gulf of Carpentaria, Australia. Mar Ecol Prog Ser 94:287-295

Young PC, Wadley VA (1979) Distribution of shallow-water epibenthic macrofauna in Moreton Bay, Queensland Australia. Mar Biol 53:83-97

Manuscript first received: April 7, 1995

Revised version accepted: July 17, 1995 


\title{
Bioindicators of pollutant exposure in the northwestern Mediterranean Sea
}

\author{
T. Burgeot ${ }^{1, *}$, G. Bocquéné ${ }^{1}$, C. Porte ${ }^{3}$, J. Dimeet ${ }^{2}$, R. M. Santella ${ }^{4}$, \\ L. M. Garcia de la Parra ${ }^{3}$, A. Pfhol-Leszkowicz ${ }^{5}$, C. Raoux ${ }^{3}$, F. Galgani ${ }^{1}$ \\ ${ }^{1}$ IFREMER, Laboratoire d'écotoxicologie, BP 1049, F-44037 Nantes, France \\ ${ }^{2}$ IFREMER, Laboratoire environnement littoral, BP 330, F-83507 La Seyne-sur-mer, France \\ ${ }^{3}$ CSIC, Dept. de quimica ambiental, Jordi Girona 18-26, E-08034 Barcelona, Spain \\ ${ }^{4}$ Columbia University, 701 West 168th Street, New York, New York 10032, USA \\ ${ }^{5}$ ENSAT, 145 Avenue Muret, F-30176 Toulouse, France
}

\begin{abstract}
Several bioindicators were used to evaluate the biological and genotoxic effects of marine pollutants near large coastal cities in the northwestern part of the Mediterranean Sea. Three target species of teleosts were selected: red mullet Mullus barbatus and 2 types of comber (Serranus hepatus and $S$. cabrilla). Induction of ethoxyresorufin-O-deethylase (EROD) activity specific for polycyclic aromatic hydrocarbons (PAH) and polychlorinated biphenyls (PCB) was measured in the livers of the fish, and inhibition of acetylcholinesterase (AChE) by organophosphorus insecticides and carbamates was measured in their muscle tissues. Maximal EROD activities (16.8 \pm 2.7 to $19.4 \pm 4.2 \mathrm{pmol} \mathrm{min}^{-1} \mathrm{mg}$ protein ${ }^{-1}$ ) recorded in red mullet near Barcelona (Spain), Milazzo (Sicily) and Ostia (Italy) indicated exposure to high pollutant concentrations. Inhibitions of $\mathrm{AChE}$ activity were low in areas remote from agricultural and industrial activity. The highest inhibitions were measured at sites of heavy industrial and domestic waste, such as Genoa and Naples (ltaly), Rio Ter (Spaın), Barcelona, and Cortiou (France). Inhibition of AChE activity was higher at a given station for younger individuals 120 to $140 \mathrm{~mm}$ in length than for those 160 to $180 \mathrm{~mm}$ long. Antioxidant enzyme activities (catalase, superoxide dismutase, glutathione peroxidase and DT-diaphorase) were measured in red mullet livers at 5 stations along the French and Spanish coasts. Catalase activity was highest at Cortiou, consistent with higher levels of pollution, and lower at Mallorca (Balearic Islands). Varying responses were obtained for the other antioxidant enzymes. Glutathione S-transferase (GST), a detoxufication enzyme, was also measured in the livers of red mullet fish and found to be significantly higher at Cortiou than at the other locations studied. Chemical measurement of PAH in surface sediment indicated the pyrolytic origin of this contaminant for all stations except Milazzo (petroleum origin). Detection of DNA adducts as a bioindicator of exposure to carcinogenic substances was tested according to 2 complementary assay techniques: enzymelinked immunosorbent assay (ELISA) and ${ }^{32}$ P-postlabeling. ELISA revealed maximal quantities of PAHDNA at Barcelona (15 adducts per $10^{8}$ nucleotides), Cap Finale (Corsica) (20.8) and Milazzo (15.5). The richest adduct profiles were detected by the ${ }^{32} \mathrm{P}$ method at Antibes (France), Santa Ponza (Balearic Islands), Milazzo and Cap Finale, with a maximum of 6.2 adducts per $10^{8}$ nucleotides at Milazzo. This multımarker approach showed that pollutant exposure levels vared according to site. With a sedimentary PAH profile apparently resulting from petroleum pollution, the Milazzo station had the greatest quantity of DNA adducts and the highest inductions of EROD activity and AChE inhibitions in $M$. barbatus and S. hepatus.
\end{abstract}

KEY WORDS: EROD - GST - AChE - Antioxidant enzymes - Biomonitoring - DNA adducts PAH Mullus barbatus

\section{INTRODUCTION}

Evaluation of the impact of contaminants in coastal areas of the Mediterranean Sea has become a priority for the countries directly concerned. With the support

-E-mail: tburgeot(aifremer.fr of international organizations (e.g. FAO: Food and Agriculture Organization of the United Nations; UNEP: United Nations Environment Programme; IOC: Intergovernmental Oceanographic Commission) for the coordination of environmental protection, a pilot program for biomonitoring in the northwest Mediterranean (MED-POL) was set up to develop sensitive and 